Bangladesh J. Pl. Breed. Genet., 28(1): 23-28, 2015

\title{
SEED PRODUCTION FEASIBILITY STUDY ON SELECTED APPROVED RICE (Oryza sativa L.) HYBRID VARIETIES
}

\author{
M. R. Islam, M. A. Khaleque $\mathrm{Mian}^{2}$ and M. S. $\mathrm{Ali}^{3}$ \\ ${ }^{1}$ Bangladesh Agricultural Development Corporation, Dilkusha, Dhaka, Bangladesh \\ ${ }^{2}$ Department of Genetics and Plant Breeding, Bangabandhu Sheikh Mujibur Rahman \\ Agricultural University, Gazipur 1706, Bangladesh \\ ${ }^{3}$ Bangladesh Agricultural Research Council, Farmgate, Bangladesh
}

\begin{abstract}
The seed production feasibility of approved hybrid varieties of rice were assessed using 15 commercially approved varieties comprising four public hybrids. Higher seed yield potentiality and earliness in maturity were the two most important indicators for popularizing hybrid rice variety in Bangladesh. The field performance of the approved hybrid rice varieties were found to vary significantly for different traits. Maximum outcrossing potential was observed in SL08HA followed by BRRI hybrid dhan $2 \mathrm{~A}$ but $\mathrm{F}_{1}$ seed yield per plant was the highest in BRRI hybrid dhan3A due to its high tillering ability followed by BRRI hybrid dhan2A, ACI1A and Heera2A. Among the tested entries $\mathrm{F}_{1}$ seed production potentiality of BRRI hybrid dhan $3 \mathrm{~A}$ was maximum indicated its commercial prospect of large scale seed production. Public bred hybrid BRRI hybrid dhan 3 and BRRI hybrid dhan 2 has immense potentiality for large scale commercialization but BRRI should ensure the quality of parental lines seed as well as supply sufficient amount of seeds according to the demand. Private company hybrids $\mathrm{ACI} 1 \mathrm{H}$ and Heera2H have good commercial prospects but seed production under Bangladesh conditions needs to be fine tune.
\end{abstract}

Key words: Outcrossing; seed production; feasibility; varieties

DOI: http://dx.doi.org/10.3329/bjpbg.v28i1.27845

\section{INTRODUCTION}

Rice is the staple food of about half of the world's population, of which more than $90 \%$ of the rice consumers inhabit in Asia. Therefore, rice plays an important role in ensuring food security and contributing poverty and malnutrition alleviation in Asia and the world. As the world's population continues to increase, there will be further demand on rice supply to meet additional consumption. Since the rice lands have been diminished due to urbanization and industrialization or agricultural diversification, the increase of rice production in the future would primarily rely on the increase of productivity. Nevertheless, it is recorded that the growth of rice productivity has declined in recent years due to little improvement in the rice yield potential. To overcome this challenge, the adoption of hybrid rice technology as experienced in China would offer an alternative to raise further the rice yield potential by exploiting the genetic expression of heterosis or hybrid vigor (FAORAP and APSA, 2014).

In Bangladesh, demand of rice is very high because most of the population consumes rice. Efforts to meet the rice needs can be done in two ways: expanding the rice planting area and increased production, or both. But in the future, expansion will be 
more difficult and expensive. Substantial improvement of rice production can be done through the adoption of hybrid rice (Nguyen 2010). Rice hybrids with a yield advantage of $20 \%$ were developed in China in the 1970s and are now planted in about $57 \%$ of the rice area in the country (Yuan, 2011). Hybrid rice has contributed significantly to food safety in China in the last 25 years. Following the success in China, Bangladesh has also started adopting hybrid rice technology since 1993 and able to develop own hybrid rice variety in 2001 .

In Bangladesh, hybrid rice developed following the three line systems. The weakness of this system is low level of $\mathrm{F}_{1}$ seed production. The low rate of seed production due to lack of high panicle exertion and low outcrossing rate of own developed CMS lines. Application of $\mathrm{GA}_{3}$ is an effective plant growth hormone which stimulates the cells elongation. $\mathrm{GA}_{3}$ is a key to obtain high seed yield in hybrid rice seed production. It can increase panicle exertion from the flag leaf, increase the rate of stigma exertion, adjust plant height, increase the duration of floret opening and make the late emerge tiller taller and productive (Virmani and Sharma, 1993; Yuan et al., 2003; Gavino et al., 2008). To enhance the efficiency of hybrid seed production, it is necessary to increase the yield of hybrid seed by improving the out crossing capacity of CMS lines (Shi-Hua et al., 2006). The advantage of hybrid rice cannot be fully utilized unless a cost effective seed production system successfully developed. Presently, use of gibberellic acid $\left(\mathrm{GA}_{3}\right)$ is almost the prerequisite for rice hybrid seed production which increases the cost of hybrid seeds. Hybrid rice seed production is highly dependent on use of gibberellic acid $\left(\mathrm{GA}_{3}\right)$. Outside China this is quite expensive (more than US\$1.00 per gram), because it is imported from China (Virmani et al., 2007). Commercial feasibility during seed production is very important of a release hybrid. Keeping in view of these needs the present investigation was undertaken to study the commercial seed production feasibility of some selected approved exotic and locally developed rice hybrids.

\section{MATERIALS AND METHODS}

The experiment was carried out at the experimental farm of Bangabandhu Sheikh Mujibur Rahman Agricultural University, Gazipur during October 2011 to June 2012. The soil type of the experimental field belongs to the Shallow Red Brown Terrace type under Agro ecological Zone (AEZ) 28 which is characterized by silty clay with $\mathrm{pH}$ value of 6.5. In total 30 parent materials of 15 hybrid rice combinations were used in this study. The seed of these parental lines were collected from different seed companies and BRRI. Seeds of all genotypes were soaked separately following company, BRRI and BADC prescribed duration gap between $\mathrm{A}$ and $\mathrm{R}$ lines for 48 hours in clothes bag. Soaked seeds were picked up from water and wrapped with straw and gunny bag to increase the temperature for facilitating germination. The germinated seeds were sown in seed bed for raising seedlings. The land was prepared thoroughly by 3-4 times ploughing and cross ploughing followed by laddering to obtain a good puddled condition. The experiment was laid out in a Randomized Complete Block Design (RCBD) with three replications. The unit plot size was 4m x 2m. Fertilizer were applied @ 270, 130, 120, 70 , and $10 \mathrm{~kg} / \mathrm{ha}$ of urea, TSP, MP, Zinc Sulphate and Gypsum, respectively. Total urea was applied in three installments at 15, 35 and 55 days after transplanting (DAT). 1/3 of MP was applied with $2^{\text {nd }}$ top dressing of urea. Thirty days old seedlings were transplanted in the main field maintaining row direction east to west. 6:1 row ratio of A and $\mathrm{R}$ lines was maintained. Synchronization of flowering was adjusted at different panicle initiation stages by applying 2\% Phosphorus solution for earliness and $1 \%$ Nitrogen fertilizer solution for delayness. Gibberellic acid $\left(\mathrm{GA}_{3}\right)$ at the rate of $120 \mathrm{~g} / \mathrm{ha}$ was used to improve panicle exertion and prolong duration of floret opening and stigma 
receptivity. Supplementary pollination was done with a bamboo stick at peak anthesis period for 3 to 4 times maintaining an interval of 30 minutes between them. Intercultural operation, irrigation and protection measures were maintained properly. Crop was harvested when it reached physiological maturity stage. Randomly ten hills were selected in each plot and the data were recorded on- plant height $(\mathrm{cm})$, number of tillers/plant, days to first flowering, days to $50 \%$ flowering, panicle length $(\mathrm{cm})$, number of spikelet/panicles, number of filled grains/panicle, out crossing rate (\%), grain yield/plant, straw yield/plant and harvest index. Data were analyzed using CROPSTAT-C and Microsoft Excel programme 2007.

\section{RESULTS AND DISCUSSION}

Results of analysis of variance are presented in Table 1. It revealed that CMS or A lines exhibited highly significant variation among themselves in respect of eleven characters evaluated.

Table 1. Analysis of variance for different characters in fifteen CMS lines during Boro, 2012-13

\begin{tabular}{|c|c|c|c|c|c|c|c|c|}
\hline \multirow[b]{2}{*}{$\begin{array}{l}\text { Source of } \\
\text { Variance }\end{array}$} & \multirow[b]{2}{*}{ df } & \multicolumn{7}{|c|}{ Characters } \\
\hline & & $\begin{array}{l}\text { Plant } \\
\text { height } \\
(\mathrm{cm})\end{array}$ & $\begin{array}{l}\text { Number of } \\
\text { tillers } \\
\text { /plant }\end{array}$ & $\begin{array}{c}\text { Days to } \\
\text { first } \\
\text { flowering }\end{array}$ & $\begin{array}{c}\text { Days to } \\
50 \% \\
\text { flowering }\end{array}$ & $\begin{array}{c}\text { Panicle } \\
\text { length } \\
(\mathrm{cm})\end{array}$ & $\begin{array}{l}\text { Number of } \\
\text { spikelets } \\
\text { /panicle }\end{array}$ & $\begin{array}{l}\text { Number of } \\
\text { filled grain } \\
\text { /panicle }\end{array}$ \\
\hline Treatment & 14 & $1638.57 * *$ & $1129.81 * *$ & $12756.5^{* *}$ & $12850.8^{* * *}$ & $99.45^{* *} *$ & $21395.4 * *$ & $4509.33 * *$ \\
\hline Replication & 2 & 0.90 & 2.79 & 55.60 & 51.60 & 19.68 & 2.62 & 10.60 \\
\hline Error (MS) & 28 & 14.32 & 14.58 & 123.07 & 158.40 & 13.18 & 29.64 & 76.58 \\
\hline $\mathrm{CV} \%$ & & 0.8 & 3.4 & 1.5 & 2.6 & 3.0 & 0.8 & 6.1 \\
\hline
\end{tabular}

* Significant at $5 \%$ and $* *$ significant at $1 \%$ level of significance

Contd. Table 1.

\begin{tabular}{l|c|c|c|c|c}
\hline \multirow{2}{*}{ Source of Variance } & \multirow{2}{*}{ df } & \multicolumn{4}{|c}{ Characters } \\
\cline { 3 - 6 } & & $\begin{array}{c}\text { Out crossing rate } \\
(\% \text { OCR) }\end{array}$ & $\begin{array}{c}\text { Grain yield } \\
\text { /plant }(\mathrm{g})\end{array}$ & $\begin{array}{c}\text { Straw yield } \\
\text { /plant }(\mathrm{g})\end{array}$ & Harvest index \\
\hline Treatment (MS) & 14 & $1622.07^{* *}$ & $840.56^{* *}$ & $3196.29^{* *}$ & $0.44^{* *}$ \\
Replication (MS) & 2 & 5.55 & 3.19 & 3.76 & 0.42 \\
Error (MS) & 28 & 40.49 & 12.89 & 19.86 & 0.97 \\
CV \% & & 6.1 & 6.9 & 3.0 & 11.1 \\
\hline
\end{tabular}

* Significant at $5 \%$ and $* *$ significant at $1 \%$ level of significance

Mean performance of CMS or A lines were shown in Table 2. Highest plant height was observed in SL08HA followed by BRRI hybrid dhan1A, BRRI hybrid dhan $2 \mathrm{~A}$ and ShaktiA. It was ranged from $98.53 \mathrm{~cm}$ to $77.93 \mathrm{~cm}$ with coefficient of variation 0.8 . Tillering ability was highest in BRRI hybrid dhan3A (33.80) compared to other CMS lines. It ranged from 12.80 to 33.80. Pandey and Awasthi (2002) reported genetic variability for number of tillers per plant while working with 21 aromatic rice genotypes. Yadav (2001) also found significant variability for number of tillers per plant in rainfed rice. Among the CMS lines LP108A was the earliest and ACI93024A was the late for days to first flowering, days to fifty percent flowering as well as maturity. Highest panicle length was noticed in BRRI hybrid dhan1A (Table 2). Flag leaf length varied significantly among the CMS lines. Rahman et al., (1997) observed the same situation while they worked with some parental lines collected from exotic and native sources. The findings of the present study were also supported by Shikder (2010) while investigating enormous exotic hybrid rice genotypes for their seed quality assessment. 
Table 2. Mean performance of CMS or A lines for yield and yield contributing characters

\begin{tabular}{l|c|c|c|c|c|c}
\hline \multicolumn{1}{c|}{ A lines } & $\begin{array}{c}\text { Plant } \\
\text { height } \\
(\mathrm{cm})\end{array}$ & $\begin{array}{c}\text { Number } \\
\text { of tillers } \\
\text { /plant }\end{array}$ & $\begin{array}{c}\text { Days to } \\
\text { first } \\
\text { flowering }\end{array}$ & $\begin{array}{c}\text { Days to } \\
50 \% \\
\text { flowering }\end{array}$ & $\begin{array}{c}\text { Days to } \\
\text { maturity }\end{array}$ & $\begin{array}{c}\text { Panicle } \\
\text { length }(\mathrm{cm})\end{array}$ \\
\hline BRAC HB-09 A & $81.00 \mathrm{~h}$ & $21.80 \mathrm{ef}$ & $101.00 \mathrm{f}$ & $105.00 \mathrm{de}$ & $134.67 \mathrm{f}$ & $20.20 \mathrm{f}$ \\
BRAC Shakti A & $95.90 \mathrm{~b}$ & $16.67 \mathrm{hi}$ & $73.33 \mathrm{~h}$ & $80.00 \mathrm{~g}$ & $107.33 \mathrm{~h}$ & $22.80 \mathrm{~cd}$ \\
BRRI hybrid dhan1A & $96.60 \mathrm{~b}$ & $20.13 \mathrm{~g}$ & $100.33 \mathrm{f}$ & $103.67 \mathrm{e}$ & $133.67 \mathrm{f}$ & $26.00 \mathrm{a}$ \\
BRRI hybrid dhan2A & $95.60 \mathrm{~b}$ & $22.80 \mathrm{e}$ & $111.00 \mathrm{~b}$ & $115.33 \mathrm{~b}$ & $145.33 \mathrm{~b}$ & $23.30 \mathrm{bc}$ \\
BRRI hybrid dhan3A & $92.40 \mathrm{c}$ & $33.80 \mathrm{a}$ & $103.33 \mathrm{ef}$ & $107.00 \mathrm{c}-\mathrm{e}$ & $137.00 \mathrm{ef}$ & $24.60 \mathrm{ab}$ \\
Heera1A & $89.60 \mathrm{~d}$ & $26.00 \mathrm{bc}$ & $110.00 \mathrm{bc}$ & $114.33 \mathrm{~b}$ & $144.33 \mathrm{bc}$ & $21.70 \mathrm{~d}-\mathrm{f}$ \\
Heera5A & $85.53 \mathrm{ef}$ & $23.20 \mathrm{de}$ & $102.33 \mathrm{f}$ & $106.33 \mathrm{c}-\mathrm{e}$ & $136.00 \mathrm{f}$ & $22.17 \mathrm{c}-\mathrm{e}$ \\
ACI1 A & $83.80 \mathrm{~g}$ & $24.60 \mathrm{~cd}$ & $103.00 \mathrm{ef}$ & $107.33 \mathrm{c}-\mathrm{e}$ & $137.33 \mathrm{ef}$ & $21.70 \mathrm{~d}-\mathrm{f}$ \\
ACI93024A & $89.80 \mathrm{~d}$ & $17.00 \mathrm{hi}$ & $140.67 \mathrm{a}$ & $144.67 \mathrm{a}$ & $175.00 \mathrm{a}$ & $24.50 \mathrm{ab}$ \\
LP70A & $86.80 \mathrm{e}$ & $20.93 \mathrm{fg}$ & $103.67 \mathrm{ef}$ & $107.33 \mathrm{c}-\mathrm{e}$ & $137.33 \mathrm{ef}$ & $20.70 \mathrm{ef}$ \\
LP106A & $86.00 \mathrm{e}$ & $15.80 \mathrm{i}$ & $106.67 \mathrm{~cd}$ & $110.67 \mathrm{bc}$ & $141.00 \mathrm{~cd}$ & $22.20 \mathrm{c}-\mathrm{e}$ \\
LP108A & $77.93 \mathrm{i}$ & $26.40 \mathrm{~b}$ & $64.00 \mathrm{i}$ & $68.00 \mathrm{~h}$ & $98.33 \mathrm{i}$ & $22.50 \mathrm{~cd}$ \\
Lal Teer GoldA & $84.20 \mathrm{f}$ & $21.00 \mathrm{fg}$ & $105.67 \mathrm{de}$ & $110.33 \mathrm{~b}-\mathrm{d}$ & $140.00 \mathrm{de}$ & $22.10 \mathrm{c}-\mathrm{e}$ \\
Lal Teer TiaA & $83.00 \mathrm{~g}$ & $17.93 \mathrm{~h}$ & $110.33 \mathrm{bc}$ & $114.33 \mathrm{~b}$ & $144.33 \mathrm{bc}$ & $22.10 \mathrm{c}-\mathrm{e}$ \\
BADC SL 08HA & $98.53 \mathrm{a}$ & $12.80 \mathrm{j}$ & $87.33 \mathrm{~g}$ & $91.33 \mathrm{f}$ & $121.33 \mathrm{~g}$ & $21.30 \mathrm{~d}-\mathrm{f}$ \\
Mean & 88.45 & 21.39 & 101.51 & 105.71 & 135.53 & 22.52 \\
Min & 77.93 & 12.80 & 64.00 & 68.00 & 98.33 & 20.20 \\
Max & 98.53 & 33.80 & 140.67 & 144.67 & 175.00 & 26.00 \\
SD & 6.25 & 5.19 & 17.39 & 17.13 & 17.43 & 1.54 \\
SE & 1.61 & 1.34 & 4.49 & 4.42 & 4.50 & 0.40 \\
CV & 0.8 & 3.4 & 2.2 & 2.6 & 1.5 & 3.0 \\
LSD value & 1.20 & 1.21 & 3.71 & 4.59 & 3.51 & 1.15 \\
\hline
\end{tabular}

Contd. Table 2.

\begin{tabular}{l|c|c|c|c|c}
\hline \multicolumn{1}{c|}{ A lines } & $\begin{array}{c}\text { Flag leaf } \\
\text { length }(\mathrm{cm})\end{array}$ & $\begin{array}{c}\text { Out } \\
\text { crossing } \\
\text { rate }(\%)\end{array}$ & $\begin{array}{c}\text { Number of } \\
\text { spikelets } \\
\text { /panicle }\end{array}$ & $\begin{array}{c}\text { Straw } \\
\text { yield/plant } \\
(\mathrm{g})\end{array}$ & $\begin{array}{c}\text { Harvest } \\
\text { Index }\end{array}$ \\
\hline BRAC HB-09 A & $16.40 \mathrm{i}$ & $19.67 \mathrm{~cd}$ & $126.80 \mathrm{~h}$ & $27.70 \mathrm{e}$ & $0.16 \mathrm{~b}-\mathrm{d}$ \\
BRAC Shakti A & $33.30 \mathrm{a}$ & $22.35 \mathrm{bc}$ & $120.80 \mathrm{i}$ & $22.40 \mathrm{f}$ & $0.14 \mathrm{c}-\mathrm{e}$ \\
BRRI hybrid dhan1A & $22.10 \mathrm{gh}$ & $19.79 \mathrm{~cd}$ & $151.20 \mathrm{~d}$ & $29.80 \mathrm{~d}$ & $0.39 \mathrm{a}$ \\
BRRI hybrid dhan2A & $24.93 \mathrm{~b}-\mathrm{d}$ & $25.00 \mathrm{~b}$ & $155.20 \mathrm{c}$ & $36.40 \mathrm{c}$ & $0.22 \mathrm{~b}$ \\
BRRI hybrid dhan3A & $26.50 \mathrm{~b}$ & $20.41 \mathrm{~cd}$ & $147.00 \mathrm{e}$ & $38.90 \mathrm{~b}$ & $0.34 \mathrm{a}$ \\
Heera1A & $25.60 \mathrm{bc}$ & $21.32 \mathrm{~cd}$ & $145.40 \mathrm{e}$ & $39.70 \mathrm{~b}$ & $0.18 \mathrm{~b}-\mathrm{d}$ \\
Heera5A & $23.90 \mathrm{c}-\mathrm{g}$ & $14.64 \mathrm{f}$ & $133.80 \mathrm{f}$ & $31.60 \mathrm{~d}$ & $0.08 \mathrm{ef}$ \\
ACI1 A & $21.10 \mathrm{~h}$ & $20.62 \mathrm{~cd}$ & $149.40 \mathrm{~d}$ & $30.10 \mathrm{~d}$ & $0.16 \mathrm{~b}-\mathrm{d}$ \\
ACI93024A & $24.90 \mathrm{~b}-\mathrm{d}$ & $10.58 \mathrm{~g}$ & $170.20 \mathrm{a}$ & $27.30 \mathrm{e}$ & $0.03 \mathrm{f}$ \\
LP70A & $23.20 \mathrm{~d}-\mathrm{g}$ & $19.72 \mathrm{~cd}$ & $131.20 \mathrm{~g}$ & $43.40 \mathrm{a}$ & $0.08 \mathrm{ef}$ \\
LP106A & $22.60 \mathrm{f}-\mathrm{h}$ & $19.07 \mathrm{de}$ & $110.80 \mathrm{k}$ & 12.901 & $0.13 \mathrm{de}$ \\
LP108A & $24.20 \mathrm{c}-\mathrm{f}$ & $7.57 \mathrm{~h}$ & 86.301 & $19.90 \mathrm{gh}$ & $0.02 \mathrm{f}$ \\
Lal Teer GoldA & $24.60 \mathrm{~b}-\mathrm{e}$ & $30.09 \mathrm{a}$ & $119.00 \mathrm{i}$ & $21.20 \mathrm{fg}$ & $0.14 \mathrm{c}-\mathrm{e}$ \\
Lal Teer TiaA & $22.80 \mathrm{e}-\mathrm{h}$ & $16.36 \mathrm{ef}$ & $116.20 \mathrm{j}$ & $19.00 \mathrm{~h}$ & $0.23 \mathrm{~b}$ \\
BADC SL 08HA & $32.10 \mathrm{a}$ & $30.95 \mathrm{a}$ & $165.20 \mathrm{~b}$ & $22.60 \mathrm{f}$ & $0.21 \mathrm{bc}$ \\
Mean & 24.55 & 19.88 & 135.23 & 28.19 & 0.17 \\
Min & 16.40 & 7.57 & 86.30 & 12.90 & 0.02 \\
Max & 33.30 & 30.95 & 170.20 & 43.40 & 0.39 \\
SD & 4.07 & 6.21 & 22.57 & 8.72 & 0.10 \\
SE & 1.05 & 1.60 & 5.83 & 2.25 & 0.03 \\
CV & 3.4 & 6.1 & 0.8 & 3.0 & 11.1 \\
LSD value & 1.41 & 2.01 & 1.72 & 1.41 & 0.03 \\
\hline
\end{tabular}

Significant variation was observed for out crossing rate among the CMS lines. The highest out crossing rate was recorded in BADC SL 08A $(30.95 \%)$ which was followed by Lal Teer GoldA (30.09\%), BRRI hybrid dhan2A (25.00\%) and BRAC 
ShaktiA (22.35\%). The lowest out crossing rate was found in LP108A $(7.57 \%)$ which was followed by ACI93024A (10.58\%), BADC SL08HA (14.64\%) and Lal Teer TiaA $(16.36 \%)$. Overall mean value for outcrossing rate was observed as 19.88. Number of spikelets/panicle was highest in ACI93024A and the lowest in LP108A (Table 3). Grain yield/plant was not measured for CMS lines due to its sterility character. Straw yield/plant varied significantly among CMS lines. In CMS lines, maximum straw yield/plant was observed in LP70A (43.40) and the lowest in LP106A (12.90). Iftekharudduala et al., (2002) reported high variation among genotypes in respect of the trait which is similar to the present study. Roy (2006) also agreed with the results of the present study. Nath (2005) also supported the above findings for straw yield per plant in T. Aman rice varieties. The highest value for harvest index was found in BRRI hybrid dhan1A (0.39) which was followed by BRRI hybrid dhan3A (0.34), Lal Teer TiaA (0.23) and BRRI hybrid dhan2A (0.22). The lowest value for harvest index was recorded in LP108A (0.02) which was followed by ACI93024A (0.03), Heera5A and LP70A (0.08) and LP106A (0.13). The mean value for harvest index was 0.17 . Results of $F_{1}$ seed production potentiality of different CMS lines crossed with restorer lines were shown in Table 3.

Table 3. $F_{1}$ seed production potentiality of different CMS lines crossed with restorer lines

\begin{tabular}{lcc}
\hline \multicolumn{1}{c|}{ A lines } & Number of $\mathbf{F}_{\mathbf{1}}$ seeds/panicle & $\mathbf{F}_{\mathbf{1}}$ seed yield per plant $\mathbf{( g )}$ \\
\hline BRAC HB09A & $25.10 \mathrm{e}$ & $9.32 \mathrm{e}$ \\
BRAC ShaktiA & $27.00 \mathrm{de}$ & $6.46 \mathrm{f}$ \\
BRRI hybrid dhan1A & $29.83 \mathrm{~cd}$ & $8.13 \mathrm{e}$ \\
BRRI hybrid dhan2A & $38.80 \mathrm{~b}$ & $14.96 \mathrm{bc}$ \\
BRRI hybrid dhan3A & $30.00 \mathrm{~cd}$ & $17.68 \mathrm{a}$ \\
Heera2A & $31.00 \mathrm{c}$ & $13.98 \mathrm{c}$ \\
Heera5A & $19.60 \mathrm{f}$ & $9.08 \mathrm{e}$ \\
ACI-1A & $30.80 \mathrm{c}$ & $16.03 \mathrm{~b}$ \\
ACI 93024A & $18.00 \mathrm{f}$ & $3.69 \mathrm{~g}$ \\
LP70A & $25.87 \mathrm{e}$ & $8.31 \mathrm{e}$ \\
LP106A & $21.13 \mathrm{f}$ & $6.48 \mathrm{f}$ \\
LP108A & $6.53 \mathrm{~g}$ & $2.84 \mathrm{~g}$ \\
Lal Teer GoldA & $35.80 \mathrm{~b}$ & $11.89 \mathrm{~d}$ \\
Lal Teer TiaA & $19.00 \mathrm{f}$ & $6.46 \mathrm{f}$ \\
BADC SL08A & $51.13 \mathrm{a}$ & $12.23 \mathrm{~d}$ \\
Mean & 27.31 & 9.84 \\
Min & 6.53 & 2.84 \\
Max & 51.13 & 17.68 \\
SD & 10.36 & 4.47 \\
SE & 2.68 & 1.16 \\
CV & 6.1 & 6.9 \\
LSD value & 2.77 & 1.13 \\
\hline
\end{tabular}

The highest amount of $\mathrm{F}_{1}$ seed yield per plant was recorded in BRRI hybrid dhan3A (17.68 g) which was followed by ACI1A (16.03 g), BRRI hybrid dhan2A (14.96 g) and Heera2A (13.98 g).The lowest value for $F_{1}$ seed yield per plant was found in LP108A (2.84 g) which was followed by ACI93024A (3.69 g), BRAC ShaktiA and Lal Teer TiaA $(6.46 \mathrm{~g})$. The overall mean value for $\mathrm{F}_{1}$ seed yield per plant was recorded 9.84 g. Among the tested entries $F_{1}$ seed production potentiality of BRRI hybrid dhan3A was highest which indicated its commercial prospect of large scale seed production. Public 
bred hybrid BRRI hybrid dhan 3 and BRRI hybrid dhan2 has immense potentiality for large scale commercialization but BRRI should ensure the quality of parental lines seed as well as supply sufficient amount of parental line seeds according to demand. Private company hybrids $\mathrm{ACI} 1 \mathrm{H}$ and Heera2H have good commercial prospects but seed production under Bangladesh condition needs to be fine tune.

\section{REFERENCES}

FAORAP and APSA (FAO Regional Office for Asia and the Pacific and Asia-Pacific Seed Association). 2014. Hybrid Rice Development in Asia: Assessment of Limitations and Potential. Proceedings of the Regional Expert Consultation on "Hybrid Rice Development in Asia: Assessment of Limitations and Potential", 2-3 July 2014, Bangkok, Thailand.

Gavino, R. B., P. Y. Abon and Jr C C. 2008. Application of geberellic acid (GA3) in dosages for three hybrid rice seed production in the Philippines. Journal of Agricultural Technology. 4(1): 183-192.

Iftekharuddaulla, K. M., M. A. Badshah, M. S. Hassain, M. K. Bashar and K. Akhter. 2002. Genetic variavility, character association and path analysis of yield components in irrigated rice (Oryza sativa L.). Bangladesh J. Pl. Breed Genet. 14(1): 43-49.

Nath, J. K. 2005. Study of genetic divergence in T.Aman rice. M.S. Thesis. Department of Genetics and Plant Breeding. Bangabandhu Sheikh Mujibur Rahman Agricultural University, Gazipur-1706, Bangladesh. 70 P.

Nguyen, N. V. 2010. Ensuring Food Security in the 21st Century with Hybrid Rice: Issues and Challenges. In: Accelerating Hybrid Rice Development, Xie, F. and B. Hardy (Eds.). International Rice Research Institute, Los Banos, Philippines, pp: 9-24.

Pandey, V. K. and L. P. Awasthi. 2002. Studies on genetic variability for yield contributing traits in aromatic rice. Crop Res. Hisar. 23(2): 214-218.

Rahman, M., B. Acharya, S. N. Shukla and K. Pande. 1997. Genetic divergence in lowland rice germplasm. Oryza. 34(3): 209-212.

Roy, A. K. 2006. Development of aromatic cytosource for hybrid rice production. Ph. D. Dissertation, Bangabandhu Sheikh Muzibur Rahman Agricultural University, Gazipur-1706, Bangladesh. 166 p.

Shi-Hua, Y., C. Ben-Yi, W. Jian-Li, S. Wei-Feng and C. Shi-Hua. 2006. Review and prospects on rice breeding and extension in China. Rice Sci., 13: 1-8.

Shikder, M. N. I. 2010. Seed quality assessment in hybrid rice genotypes. Ph. D. Dissertation, Bangabandhu Sheikh Muzibur Rahman Agricultural University, Gazipur-1706, Bangladesh. 187 p.

Virmani, S. S. and H. L. Sharma. 1993. Manual for Hybrid Rice Seed Production. IRRI. Manila. Philippines. 72 p.

Virmani, S. S., C. X. Mao, R. S. Toledo, M. Hossain and A. Janaiah. 2007. Hybrid rice seed production technology and its impact on seed industries and rural employment opportunities in Asia.

Yadav, R. K. 2001. Variation in local accessions of rice collection under rainfed condition in Chattisgarh. Indian J. Dry land Agril.Res. Dev. 16(2): 168-169.

Yuan, G. F. (2011) Development of hybrid rice and its prospect. Chin Agric Sci Bull 27(1 5): 6-11 (in Chinese with English abstract)

Yuan L, Wu X, Liao F, Ma G, Xu Q. 2003. Hybrid Rice Technology. China Agricultural Press. Beijing, China. 132p. 